\title{
A Promoter of Italian Language and Culture in Iceland: Pórhallur Porgilsson
}

\section{by Mauro Barindi}

Whenever one wishes to sketch an overview of the presence of Italian language and culture in the Nordic countries, Iceland stands out as the nation where Italian studies have hardly ever established firm roots and blossomed into a solid scholarly tradition. Amongst the few to have contributed to making this presence less ephemeral, also and especially at the institutional level, is Pórhallur Porgilsson.

Born on the 3rd April 1903 in Knarrahöfn, in the Dalasýsla area-in the "deep north" of Iceland- Pórhallur Porgilsson moves to Reykjavík to pursue high-school studies, which he completes in 1922. In the years 1923-1929, he reads roman languages and literatures at the universities of Grenobles, Paris and Madrid. During the same period, he also visits Italy on a number of occasions.

Back in his homeland, Pórhallur Porgilsson feels intellectually stimulated by his recent Continental experiences and is fully aware of the paucity of editorial and noneditorial activities concerning the teaching of roman languages in Iceland. Thus, he decides to write several teaching manuals in his mother tongue devoted to Spanish, French and Italian, all of which are to be published in Reykjavík: Kennslubók í spænsku [Spanish teaching manual, (1931)], Kennslubók í íölsku [Italian teaching manual, (1932-37; 1949²)]-which is most relevant for this short article-, Spænsk málfræði handa framhaldsnemendum [Spanish grammar for advanced students, (1944)], Spænsk lestrarbók [Spanish reader, (1948)], and Frönsk hljóðfræði [French phonetics, (1951)].

The teaching manual devoted to the Italian language is issued in three consecutive volumes: I. Ítölsk málfræði-Ágrip [Italian grammar-outline, (1932)], II. Ítalskislenskir samtalskaflar og málfræðingar [Italian-Icelandic dialogues and grammar, (1935)], III.-IV. Ítalskir leskaflar með ítalsk-íslensku orðasafni [Italian readings with Italian-Icelandic lexicon, (1937)]. These three volumes will be re-edited and published as a single larger volume in 1949, under the title: Kennslubók í ítölsku- 


\section{Nordicum-Mediterraneum}

Málfræði, málfræðiæfingar, daglegt mál, fróðleikskaflar, sögur og pættir-Önnur útgáfa, aukin og breytt [Italian teaching manual-grammar, grammar exercises, phrases, trivia, stories and excerpts-Second edition, extended and modified]. These publications are, if not the first, some of the earliest manuals in Icelandic devoted to the teaching and learning of the Italian language, and the most comprehensive.

Compared to the volumes published between 1932 and 1937, the 1949 volume offers, firstly and most obviously, the advantage of bringing together all the materials previously dispersed in three different volumes. Secondly, the 1949 volume presents an internal organisation that is more extensive and diversified; indeed, one could define it more "modern," given its denser structure and contents. For example, although it preserves the same order of topics, the grammatical section is developed further and enriched with more detailed and more accurate explanatory notes. Moreover, a novel historical appendix on Italian phonetics is added (Viðbætir: Frá latínunni til ítölskunnar [Appendix: from Latin to Italian], p.84), which is compiled most rigorously. This addition was not at all episodic, for it derived from Pórhallur porgilsson's studies in roman philology, pursued in France and Spain. A certain attention to philology was already present in the 1932 volume, in the section dealing with the phonetic notation of the Italian language, whereby Pórhallur Porgilsson adopted the symbols of the International Phonetic Alphabet (IPA).

As regards the sections concerning the exercises and the readings (1939 ed., chapters: II. Málfræðiæfingar [Grammar exercises] and III. Úr daglega lífinu. Samtöl og leskaflar [Daily life: conversation and readings]), the author reshuffles thoroughly both the order and the contents. Due to late historical events, the paragraph about Italian Colonies is removed in the 1949 volume. At the same time, a possibly intentional oversight perpetuates its anachronistic character by preserving in the text exclamations like Evviva l'Italia! Viva il Duce! (1935 ed., p.54; 1939 ed., p.131).

The 1932 edition contains also several curious terminological choices by the author. For instance, 'espresso' is translated as 'eimkaffi' (p.28) i.e. something like 'coffee distillate'-evidently, the Italian neologism had not yet entered the Icelandic parlance. Old-time 'quill and pen' (p.36) are taken to be the instruments for writing, whereas the more modern-sounding 'form' (p.38) leads to the inexorable jargon of notorious bureaucracy. Overall, the idioms utilized in this edition belong to a style that would 


\section{Nordicum-Mediterraneum}

be unacceptable today, for it abounds with dialogues making use of archaic expressions and pompous phrases that would result risible or bizarre to the modern reader.

Progressively more generous is the selection of readings from Italian writers. The 1937 volume contained only four names: Annie Vivanti, Giovanni Papini, Grazia Deledda and Luigi Pirandello. The 1939 volume contains instead ten names, under the chapter IV. Sögur og pættir úr ítölskum nútimabókmentum [Stories and excerpts from Italian literature], p.193: L. Pirandello, G. Papini, Collodi (Carlo Lorenzini), Edmondo De Amicis, Ulderico Tegani, R. Balsamo Crivelli, Renato Fucini, Guido Marta, Silvio Pellico and Alessandro Manzoni. As regards the section about the Italian civilisation, novel additions are present in the chapters Cultura in Italia (Insegnamento elementare e medio; Università ed istituti superiori) [Culture in Italy (primary education; higher education)], La religione [Religion] and the overview Letteratura italiana [Italian literature], whilst Sunto storico [Historical overview] is left unaltered.

In addition to his precious and groundbreaking production of didactic tools for the study of Italian language and culture, Pórhallur Porgilsson represents Italy and its language institutionally as well. This, on two important occasions: the 1934 opening of the Italian Consulate in Iceland-he will be the Italian consul in Iceland until the day of his death, 22nd June 1958; the 1940 creation of an Italian (and Spanish) professorship at the University of Iceland-he will hold it from 1940 to 1942.

Teaching Italian was for him something that went beyond his university professorship. It was a constant mission, as he gave private lessons in Italian for most of his life, in a country where very few people were familiar with that language.

Pórhallur Porgilsson's sudden death halted his research on the Italian sources retrievable in Iceland. Beginning in 1943, he worked as a librarian at the National Library and started to compile and, fortunately, to publish, a comprehensive catalogue of all the written materials acquired by the Library that pertained to the Latin-roman linguistic area. Before his demise, Pórhallur Porgilsson succeeded in publishing two articles on this research. The former was issued in 1954 and is dedicated to France. The latter was issued in 1958, dedicated to Italy and entitled: 
Bibliographiae latino-romanico-islandicae tentamen. Fasc. II: scripta e fontibus italicis - Drög að skrá um ritverk á íslenzku að fornu og nýju af latneskum eða rómönskum uppruna - II - Ítalía [Draft of bibliography of ancient and recent Icelandic sources of Latin and roman origin-II-Italy]. Published in the year of Pórhallur Porgilsson's death, it is the conclusive seal to a valuable and praiseworthy life of scholarship on, and friendship with, Italy in Iceland.

(English translation by Giorgio Baruchello)

\section{REFERENCES}

Ólafur P. Kristjánsson, Kennaratal á Íslandi, II, Reykjavík, 1965

Guðni Jónsson, Saga Háskóla Íslands, Reykjavík, 1961

MAURO BARINDI (b.1964), Phd in Romance Philology (Madrid Complutense University, Spain), researcher of Romanian Language and Philology, teacher of Italian at the Italian Cultural Institute in Tel Aviv, Israel, has published several scholarly articles and participated to international meetings and conferences. 